Çukurova Üniversitesi Mühendislik Mimarlık Fakültesi Dergisi, 33(4), ss. 185-196, Aralık 2018

Çukurova University Journal of the Faculty of Engineering and Architecture, 33(4), pp. 185-196, December 2018

\title{
Ülkemizdeki Enerji Santral Yatırımlarının AHP Yöntemi ile Değerlendirilmesi
}

\author{
Çetin Önder İNCEKARA*1
}

${ }^{1}$ BOTAŞ, Ankara

$\ddot{\mathbf{O z}}$

Geliş tarihi: $10.05 .2018 \quad$ Kabul tarihi: 25.12 .2018

Ülkelerin nüfus artışı, insanların yaşam standartlarının yükselmesi, teknolojik gelişmeler insanları enerjiye bağımlı hale getirerek enerji tüketiminin artırmasına sebep olmaktadır. Bu durumdan dolayı ülkelerin enerjiye bağımlılığı her geçen gün arttırmaktadır ve ülkelerin kendi enerji kaynaklarını/gerçeklerini dikkate alarak enerji planlamasını yapmasını zorunlu kılmaktadır. Çalışmada enerji konusunda kamuda ve özel sektörde çalışan yöneticiler ile yapılan görüşmeler/anketler neticesinde ülkemizde inşaası planlanan 13 tip enerji santrali seçimi için 6 ana kriter ve ilgili 31 alt kriter belirlenmiştir. Enerji santrallerinin seçimi yapılırken çok kriterli karar verme yöntemlerinden Analitik Hiyerarşi Prosesinden (AHP) faydalanılmıştır, çözüm için Excel'de makrolar yazılmıştır. Çıkan sonuçlar doğrultusunda enerji santralinin seçilme gerekçesi irdelenerek; ETKB'nın 2023 yılı stratejik enerji hedefleri ile karşılaştııılmıştır.

Anahtar Kelimeler: Çok kriterli karar verme, AHP, Enerji yatırım planlaması, Türkiye

\section{Evaluation of Power Plant's Investments in Turkey by using AHP Approach}

\begin{abstract}
The population growth of the countries, increasing living standards and technological developments cause people to become more energy dependent and cause to increase energy consumption. This situation increases the energy dependency of all countries day by day and each country should make its own energy planning taking into account its own energy resources and energy facts of the country. As a result of the surveys/interviews conducted with the energy managers working in Turkey's public and private sectors; 6 main criteria and 31 related sub-criteria have been determined for the selection of 13 types of power plants planned to be constructed in Turkey. While planning/choosing power plants, the Analytical Hierarchy Process (AHP) is used as multi-criteria decision making method. For the solution Excel is used and Excel's macros are written. In the light of the results, the reason for choosing the power plant is examined and the results are compared with the MENR's year 2023 objectives/goals stated in "Energy Strategy" document.
\end{abstract}

Keywords: Multi-criteria decision making, AHP, Energy investment planning, Turkey

*Sorumlu yazar (Corresponding author): Dr. Çetin Önder İNCEKARA, cetinincekara@gmail.com 


\section{GíRiș}

Enerji insanlığın ve uygarlığın gelişiminde temel unsurdur ve enerji yaşamın her alanında karşımıza çıkmaktadır. Dünyada ülkelerin kişi başına ürettiği ve tükettiği enerji miktarı ülkenin refah düzeyini göstermektedir. Bu kapsamda enerjinin üretilen ve kullanılan biçimleri arasında elektrik enerjisi en önemli olanıdır. Ülkemizde elektrik enerjisi fosil yakıtlardan (kömür (ithal kömür, taş kömürü, linyit, asfaltit ve bitümlü şist), petrol, doğalgaz) ve yenilenebilir kaynaklardan (güneş, hidro, rüzgar, jeotermal, biyokütle) elde edilmektedir.

19. yüzyılın sonlarından itibaren enerji tüketiminde yaklaşık her çeyrek yüzyılda bir belirli bir enerji hammaddesi önem kazanmıştır. 19. yüzyılın sonlarıyla 20. yüzyılın başlarında dünya genelinde temel enerji kaynağını kömür oluşturmuştur. Kömürün neredeyse rakipsiz olarak görüldüğü bu dönemi petrolün egemenliği takip etmiştir. $\mathrm{Bu}$ dönem İkinci Dünya Savaşı sonrasında başlamış, kömür yerini petrole bırakmıştır. Petrolün hakimiyeti 1979 y1llındaki petrol krizlerine kadar devam etmiştir. 1979 yıllından sonra ise petrol yerini doğal gaza bırakmaya başlamıştır. Özellikle ekolojik dengeler açısından görülen sakıncalarla birlikte nükleer enerji birçok ülkede sınırlandırılmış, temiz çevre anlayışıyla doğal gaz sıklıkla kullanılmaya başlanmıştır. Günümüzde ise gerek fosil yakıtların tükenmesi gerekse bunların neden olduğu çevre zararları nedeniyle yenilenebilir enerji kaynaklarına olan talep artmıştır [1].

Avrupa Birliği'de yenilenebilir enerji politikalarının üzerinde önemle durmaktadır. Avrupa'da 2020 yilında üretilen elektrik enerjisinin \%20'sinin yenilenebilir enerji kaynaklarından olması planlanmaktadır [2]. Bunun altında yatan temel nedenler ise: AB'nin enerjide dişa bağımlılı̆̆ının (özellikle petrol ve doğalgaz yönünden) giderek artması nedeniyle enerji kaynak çeşitlendirilmesi zorunluluğunun farkına varması ile karbondioksit salınımında dünya sıralamasında üçüncü sırada olmasıdır. Bu kapsamda AB ülkeleri yenilenebilir enerji kaynaklarından elektrik üretmek için büyük yatırımlar yapmaktadır. Bu duruma örnek olarak Almanya ve İspanya verilebilir. Alman hükümeti 2010 yılında enerji sektörü yol haritası olan "Energy Concept 2050" i kabul etmiştir. Almanya'nın hedefi: yenilenebilir enerji kaynaklarının toplam elektrik üretiminde; 2020 yilinda \%35'e, 2050 yilında ise \%80'e çıkarmaktır. İspanya ise elektrik üretiminde yenilenebilir enerji payı; 1998 yılında \%12'den 2012 yılında \%35'e ulaşmıştır. World Energy Organization (WEO)'e göre 2035 yılında dünyada kurulacak yeni enerji santrallerinin yarısından çoğunu güneş, hidrolik ve rüzgar gibi yenilenebilir enerji kaynakları oluşturacaktır [3].

ETKB [1,4] tarafından ülkemizde güneşe dayalı elektrik üretim kapasitesinin yılda 380 milyar kWh, hidrolike dayalı 140 milyar $\mathrm{kWh}$, rüzgara dayalı 144 milyar kWh, jeotermale dayalı 15,2 milyar $\mathrm{kWh}$, biyokütleye dayalı 93 milyar $\mathrm{kWh}$, taş kömürüne dayalı 11 milyar $\mathrm{kWh}$, linyite dayalı 118 milyar $\mathrm{kWh}$, asfaltit ve bitümlü şiste dayalı 16 milyar $\mathrm{kWh}$ olduğu tahmin edilmektedir. Ülkemizin söz konusu enerji gerçeklerini dikkate alarak ülkemizin enerji santral planlama çalışması yapılmıştır.

\section{MATERYAL VE METOT}

\section{1. Çok Kriterli Karar Verme: AHP Yöntemi}

Ülkemizde elektrik üretimi çeşitli enerji kaynakları kullanan santraller ile yapılmaktadır. Elektrik santral tipinin seçimi ise enerji üretim kriterlerine bağlı olarak değişkenlik göstermektedir. Literatürde kriterlere bağlı elektrik santral tipinin seçimi çok kriterli karar verme (ÇKKV) problemi olarak tanımlanmaktadır. Zionts [5] tarafından çok kriterli karar verme; çoklu ve birbiriyle çatışan amaçların/kriterlerin gerçekleştirilmek istendiği problemlerin çözümüne verilen genel bir isimdir.

Analitik Hiyerarşi Süreci (AHP); Karar Vericiler (KV) karar verme aşamasında seçim kriterlerini birleştirme seçeneğini sunan bir yöntemdir [6,7]. AHP'de, ilk olarak KV görüşleri doğrultusunda; kriterler ve alt kriterleri belirlenir ve hiyerarşik yapı oluşturulur. AHP her sorun için amaç, kriter, olası alt kriter seviyeleri ve seçeneklerden oluşan 
hiyerarşik bir model kullanır $[7,8]$. Çalışmada enerji santrallerin seçiminde literatürde ikili karşılaştırma yöntemi Analitik Hiyerarşi Süreci (AHP) çok sık kullanıldığından [9,10-14] çalışma kapsamında AHP yöntemi kullanılmıştır. Çalışmada kamuda ve özel sektör enerji yöneticileri (KV) ile görüşülerek çalışmanın kriterleri ve alt kriterleri belirlenmiştir. Görüşülen kişilerin dağılımı şu şekildedir: özel sektörde çalışan enerji şirketi yöneticilerinin sayısı 12 (5'i 15 y1l ve üzeri, 3'ü 10-15 yıl, 4'ü 8-10 y1l tecrübeli) dir, Enerji ve Tabii Kaynaklar Bakanlığı'na bağlı enerji şirketlerinde çalışan yöneticilerinin sayısı ise 18 (8'i 15 yıl ve üzeri, 6' 1 10-15 yıl, 4'ü 8-10 y1l tecrübeli)'dir. Çalışmada KV'lerin (enerji yöneticilerinin) cevaplarının ortalaması alınmıştır.

Çalışmada ülkemizde kullanılan/kullanılacak olan tüm santraller dikkate alınmıştır, santrallerin puanları; enerji konusunda uzman kamuda ve özel sektörde üst düzeyde çalışan kişiler (KV) tarafından 1-9 skalasına göre (AHP skalası) doldurulan anketler ve görüşmeler neticesinde oluşturulmuştur. Anketler ve görüşme sonuçlarına göre; 13 enerji santrali için 6 ana kriter (çevresel etkenler, santral teknolojisi etkisi, santral etkileri, santral karlılık durumu, santral kurulum, santral birim elektrik üretim maliyeti) ve ilgili 31 alt kriter belirlenmiştir. Son yıllarda literatürde enerji problemlerinin çözümünde AHP yöntemi çok sık kullanıldığından çalışma kapsamında AHP yöntemi kullanılmıştır. Ana kriterlerin AHP hesaplama prosedürüne [7,15] göre yapılan değerlendirmeler sonucu kriterlerin ikili karşılaştırma matrisleri oluşturulmuştur. Çalışmada enerji santrallerin seçimi problemi için dünyada en çok kullanılan programlardan birisi olan Excel Çözücüsü (Microsoft firmasının) programı kullanılmıştır, çözüm için Excel'de makrolar yazılmıştır. Tüm bilgisayarlarda Windows'un çok yaygın kullanılması Excel programının kullanılmasında önemli bir rol oynamıştır.

\section{BULGULAR VE TARTIŞMA}

Karar vericiler ile görüşülerek çalışmada ülkemizde kullanılan/kullanılacak 13 enerji santrali için kullanılan kriterler ve alt kriterleri aşağıda tanımlanmıştır.

\section{1. Çevresel Etkenler}

2. Santral Teknolojisi Etkisi

3. Santralin Etkileri

4. Santralin Karlılık Durumu

5. Santral Kurulum Durumu

6. Santral Birim Elektrik Üretim Maliyeti’dir.

\section{1. Çevresel Etkenler}

Yeni kurulacak santrallerin çevreye etkisi değerlendirilmiştir. Söz konusu ana kriterin değerlendirilmesi amacıyla beş alt kriter aşağıda detaylı anlatılmıştır.

i. Su Kaynakları Kullanımı/Tahribatı: Elektrik santrallerinin içme, kullanma suyuna, su kaynaklarına etkisi bu madde kapsamında değerlendirilmiştir.

ii. Çevreyi Kirletici Zararlı Gaz Salınım Miktarı: Elektrik santrallerinin çevreye saldığ zararlı gaz miktarları ve çeşitleri, partikül miktarları bu madde kapsamında değerlendirilmiştir.

iii. Görüntü Kirliliği: Elektrik santrallerinin çevreye, hayvanlara ve insanlara verdiği görüntü ve engel olma durumu açısından oluşturduğu zararlar bu madde kapsamında değerlendirilmiştir.

iv. Diğer Canlılara Etkiler: Elektrik santrallerinin kurulumu aşamasında, işletmesi aşamasında canlılara verdiği zararlar bu madde kapsamında değerlendirilmiştir.

v. Tesisin Kapladığı Hacimsel Alanın Etkileri: Elektrik santrallerinin kapladığı hacimden dolayı çevreye, hayvanlara etkisi bu madde kapsamında değerlendirilmiştir. Örnek olarak kömür santrallerinin bacası, rüzgar türbinlerinin pervaneleri (kanatları) verilebilir.

Çalışmada uygulanan AHP hiyerarşisi Şekil 1'de verilmiştir. "Çevresel Etkenler” ana kriterinin Karar Vericiler tarafından değerlendirilmesi Çizelge 1'de sunulmuştur. 


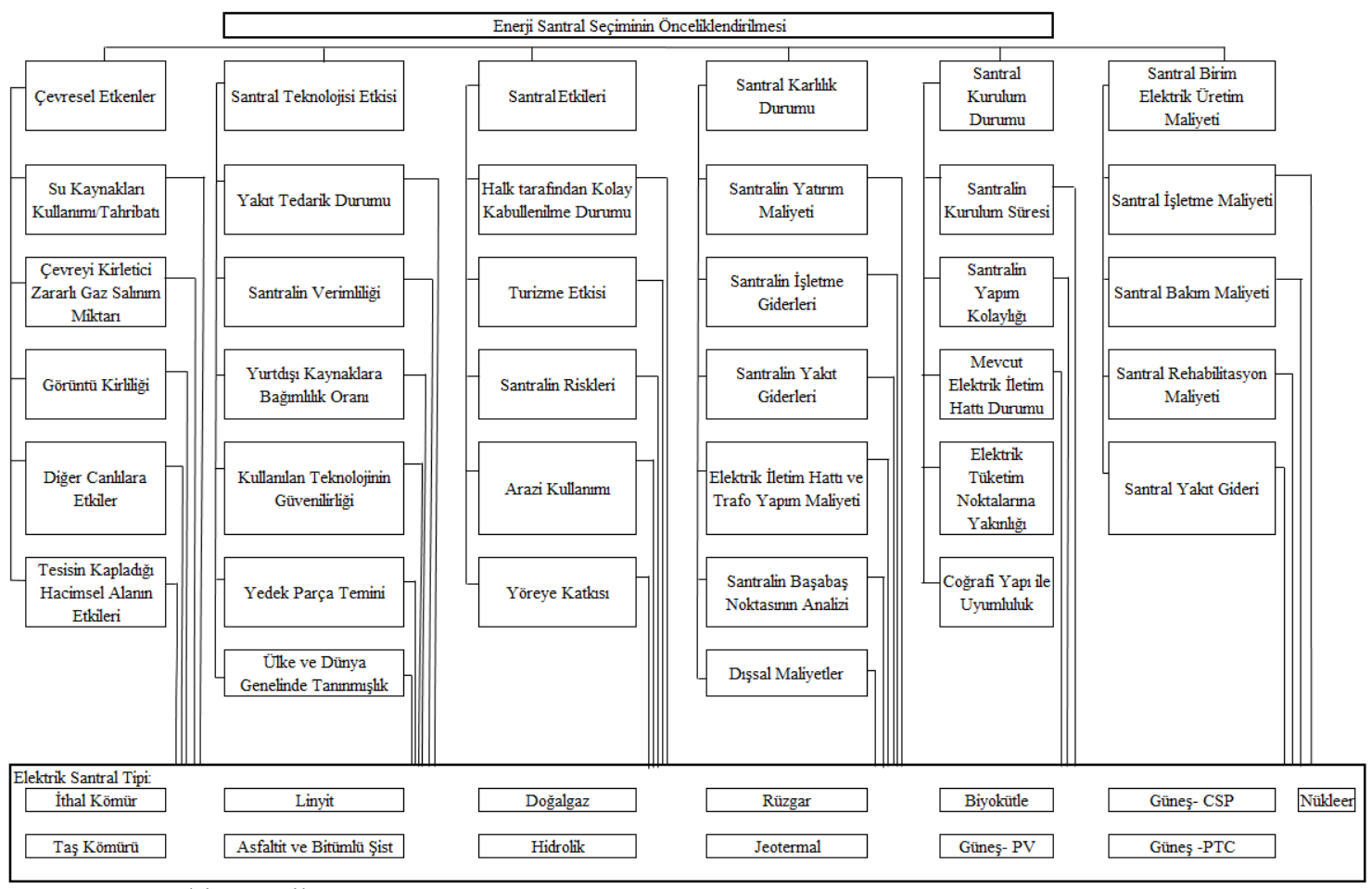

Şekil 1. AHP hiyerarşik yapı

Çizelge 1. Çevresel etkenler ana kriterinin ikili karşılaştırma matrisi

\begin{tabular}{|l|c|c|c|c|c|c|c|c|c|c|c|c|c|}
\hline & $\mathrm{P} 1$ & $\mathrm{P} 2$ & $\mathrm{P} 3$ & $\mathrm{P} 4$ & $\mathrm{P} 5$ & $\mathrm{P} 6$ & $\mathrm{P} 7$ & $\mathrm{P} 8$ & $\mathrm{P} 9$ & $\mathrm{P} 10$ & $\mathrm{P} 11$ & $\mathrm{P} 12$ & $\mathrm{P} 13$ \\
\hline P1 & 1 & 1 & $1 / 2$ & $1 / 2$ & $1 / 4$ & $1 / 7$ & $1 / 7$ & $1 / 7$ & $1 / 5$ & $1 / 8$ & $1 / 7$ & $1 / 7$ & 4 \\
\hline P2 & 1 & 1 & $1 / 2$ & $1 / 2$ & $1 / 5$ & $1 / 7$ & $1 / 7$ & $1 / 7$ & $1 / 5$ & $1 / 8$ & $1 / 7$ & $1 / 7$ & 4 \\
\hline P3 & 2 & 2 & 1 & $1 / 2$ & $1 / 5$ & $1 / 7$ & $1 / 7$ & $1 / 7$ & $1 / 5$ & $1 / 8$ & $1 / 7$ & $1 / 7$ & 5 \\
\hline P4 & 2 & 2 & 2 & 1 & $1 / 5$ & $1 / 7$ & $1 / 7$ & $1 / 7$ & $1 / 5$ & $1 / 8$ & $1 / 7$ & $1 / 7$ & 5 \\
\hline P5 & 4 & 5 & 5 & 5 & 1 & $1 / 4$ & $1 / 6$ & $1 / 5$ & $1 / 4$ & $1 / 6$ & $1 / 6$ & $1 / 6$ & 6 \\
\hline P6 & 7 & 7 & 7 & 7 & 4 & 1 & $1 / 5$ & $1 / 4$ & $1 / 3$ & $1 / 3$ & $1 / 3$ & $1 / 3$ & 8 \\
\hline P7 & 7 & 7 & 7 & 7 & 6 & 5 & 1 & $1 / 3$ & 2 & 2 & 3 & 3 & 9 \\
\hline P8 & 7 & 7 & 7 & 7 & 5 & 4 & 3 & 1 & 3 & 1 & 1 & 1 & 9 \\
\hline P9 & 5 & 5 & 5 & 5 & 4 & 3 & $1 / 2$ & $1 / 3$ & 1 & 2 & 3 & 3 & 8 \\
\hline P10 & 8 & 8 & 8 & 8 & 6 & 3 & $1 / 2$ & 1 & $1 / 2$ & 1 & $1 / 2$ & 2 & 9 \\
\hline P11 & 7 & 7 & 7 & 7 & 6 & 3 & $1 / 3$ & 1 & $1 / 3$ & 2 & 1 & 1 & 9 \\
\hline P12 & 7 & 7 & 7 & 7 & 6 & 3 & $1 / 3$ & 1 & $1 / 3$ & $1 / 2$ & 1 & 1 & 9 \\
\hline P13 & $1 / 4$ & $1 / 4$ & $1 / 5$ & $1 / 5$ & $1 / 6$ & $1 / 8$ & $1 / 9$ & $1 / 9$ & $1 / 8$ & $1 / 9$ & $1 / 9$ & $1 / 9$ & 1 \\
\hline
\end{tabular}

\subsection{Santral Teknolojisi Etkisi}

Son y1llarda elektrik santrallerin teknolojileri hızla gelişmektedir. $\mathrm{Bu}$ duruma özellikle güneş panellerinin teknolojilerinde rastlamaktayız. Söz konusu ana kriterin değerlendirilmesi amaciyla altı alt kriter şunlardır: i. Yakıt Tedarik Durumu: Santrallerin elektrik üretiminde yakıt ihtiyacı vardır. Bu alt kriterde santrallerinin elektrik üretimi için yakıtını ne kadar zamanda, ne kadar miktarda ve ne maliyetle sağladığı irdelenmiştir. 
ii. Santralin Verimliliği: Kurulacak elektrik santrallerinin verimliliği bu madde kapsamında değerlendirilmiştir.

iii. Yurtdışı Kaynaklara Bağımlılık Oranı: Elektrik santrallerinin kurulum ve işletme aşamasında kullanılan ekipman ve malzemelerin tedariki açısından yurtdışı kaynaklara bağımlılı̆̆ bu madde kapsamında değerlendirilmiştir.

iv. Kullanılan Teknolojinin Güvenilirliği: Elektrik santrallerinin enerji üretiminde kullanılan teknolojinin yaygınlığı, güvenilirliği bu madde kapsamında değerlendirilmiştir. v. Yedek Parça Temini: Elektrik santrallerinin yedek parça temininin kolaylığı bu madde kapsamında değerlendirilmiştir.

vi. Ülke ve Dünya Genelinde Tanınmışılı: Kurulacak elektrik santrallerinde kullanılan teknolojinin ülke/dünya genelinde tanınmışlığ1, kullanım sıklığı, bakım onarım kolaylığı bu madde kapsamında değerlendirilmiştir.

"Santral Teknolojisi Etkisi" ana kriterinin Karar Vericiler tarafından değerlendirilmesi Çizelge 2'de sunulmuştur.

Çizelge 2. Santral teknolojisi etkisi ana kriterinin ikili karşılaştırma matrisi

\begin{tabular}{|l|c|c|c|c|c|c|c|c|c|c|c|c|c|}
\hline & P1 & P2 & P3 & P4 & P5 & P6 & P7 & P8 & P9 & P10 & P11 & P12 & P13 \\
\hline P1 & 1 & $1 / 2$ & $1 / 3$ & $1 / 3$ & $1 / 3$ & $1 / 6$ & $1 / 8$ & $1 / 5$ & $1 / 4$ & $1 / 7$ & $1 / 6$ & $1 / 6$ & 1 \\
\hline P2 & 2 & 1 & $1 / 2$ & $1 / 2$ & $1 / 4$ & $1 / 6$ & $1 / 6$ & $1 / 5$ & $1 / 4$ & $1 / 6$ & $1 / 5$ & $1 / 4$ & 3 \\
\hline P3 & 3 & 2 & 1 & $1 / 2$ & $1 / 4$ & $1 / 6$ & $1 / 6$ & $1 / 5$ & $1 / 4$ & $1 / 6$ & $1 / 5$ & $1 / 4$ & 4 \\
\hline P4 & 3 & 2 & 2 & 1 & $1 / 4$ & $1 / 6$ & $1 / 6$ & $1 / 5$ & $1 / 4$ & $1 / 6$ & $1 / 5$ & $1 / 4$ & 4 \\
\hline P5 & 3 & 4 & 4 & 4 & 1 & $1 / 5$ & $1 / 7$ & $1 / 7$ & $1 / 7$ & $1 / 7$ & $1 / 7$ & $1 / 5$ & 2 \\
\hline P6 & 6 & 6 & 6 & 6 & 5 & 1 & $1 / 3$ & 3 & 4 & $1 / 3$ & $1 / 2$ & $1 / 2$ & 9 \\
\hline P7 & 8 & 6 & 6 & 6 & 7 & 3 & 1 & 4 & 4 & 2 & 3 & 3 & 9 \\
\hline P8 & 5 & 5 & 5 & 5 & 7 & $1 / 3$ & $1 / 4$ & 1 & 2 & $1 / 3$ & $1 / 2$ & $1 / 2$ & 8 \\
\hline P9 & 4 & 4 & 4 & 4 & 7 & $1 / 4$ & $1 / 4$ & $1 / 2$ & 1 & $1 / 3$ & $1 / 2$ & $1 / 2$ & 7 \\
\hline P10 & 7 & 6 & 6 & 6 & 7 & 3 & $1 / 2$ & 3 & 3 & 1 & $1 / 2$ & 3 & 9 \\
\hline P11 & 6 & 5 & 5 & 5 & 7 & 2 & $1 / 3$ & 2 & 2 & 2 & 1 & 2 & 7 \\
\hline P12 & 6 & 4 & 4 & 4 & 5 & 2 & $1 / 3$ & 2 & 2 & $1 / 3$ & $1 / 2$ & 1 & 7 \\
\hline P13 & 1 & $1 / 3$ & $1 / 4$ & $1 / 4$ & $1 / 2$ & $1 / 9$ & $1 / 9$ & $1 / 8$ & $1 / 7$ & $1 / 9$ & $1 / 7$ & $1 / 7$ & 1 \\
\hline
\end{tabular}

\subsection{Santralin Etkileri}

İnşaa edilecek elektrik santrallerinin yatırımın insanlara, doğaya ve birbirlerine olan ilişkileri bu bölümde değerlendirilmiştir. Söz konusu etkilerin değerlendirilmesi amaciyla beş alt kriter aşağıda sunulmuştur.

i. Halk tarafindan Kolay Kabullenilme Durumu: Kurulacak elektrik santrallerinin yöre halkı tarafindan kabul edilebilirliği bu madde kapsamında değerlendirilmiştir.

ii. Turizme Etkisi: Kurulacak elektrik santrallerinin turizme etkisi bu madde kapsamında değerlendirilmiştir. iii. Santralin Riskleri: Elektrik santrallerinin bulunduğu yöreye oluşturduğu riskler bu madde kapsamında değerlendirilmiştir.

iv. Arazi Kullanımı: Kurulacak elektrik santrallerinin kullandığ değerlendirilmiştir.

v. Yöreye Katkısı: Kurulacak elektrik santrallerinin yöreye katkısı bu madde kapsamında değerlendirilmiştir.

"Santralin Etkileri” ana kriterinin Karar Vericiler tarafından değerlendirilmesi Çizelge 3'de sunulmuştur. 
Çizelge 3. Santralin etkileri ana kriterinin ikili karşılaştırma matrisi

\begin{tabular}{|l|c|c|c|c|c|c|c|c|c|c|c|c|c|}
\hline & P1 & P2 & P3 & P4 & P5 & P6 & P7 & P8 & P9 & P10 & P11 & P12 & P13 \\
\hline P1 & 1 & $1 / 2$ & $1 / 3$ & $1 / 3$ & 1 & $1 / 4$ & $1 / 4$ & $1 / 3$ & $1 / 3$ & $1 / 7$ & $1 / 6$ & $1 / 5$ & $1 / 2$ \\
\hline P2 & 2 & 1 & $1 / 2$ & $1 / 2$ & $1 / 2$ & $1 / 4$ & $1 / 4$ & $1 / 4$ & $1 / 3$ & $1 / 5$ & $1 / 4$ & $1 / 4$ & $1 / 3$ \\
\hline P3 & 3 & 2 & 1 & $1 / 2$ & $1 / 2$ & $1 / 4$ & $1 / 4$ & $1 / 4$ & $1 / 3$ & $1 / 5$ & $1 / 4$ & $1 / 4$ & $1 / 4$ \\
\hline P4 & 3 & 2 & 2 & 1 & 1 & $1 / 4$ & $1 / 4$ & $1 / 3$ & $1 / 3$ & $1 / 6$ & $1 / 5$ & $1 / 5$ & $1 / 4$ \\
\hline P5 & 1 & 2 & 2 & 1 & 1 & 3 & 4 & 4 & 6 & 6 & 6 & 3 & $1 / 5$ \\
\hline P6 & 4 & 4 & 4 & 4 & $1 / 3$ & 1 & 4 & 4 & 4 & 5 & 4 & 4 & $1 / 7$ \\
\hline P7 & 4 & 4 & 4 & 4 & $1 / 4$ & $1 / 4$ & 1 & 1 & 2 & 3 & 4 & 4 & $1 / 8$ \\
\hline P8 & 3 & 4 & 4 & 3 & $1 / 4$ & $1 / 4$ & 1 & 1 & 4 & 3 & 4 & 4 & $1 / 8$ \\
\hline P9 & 3 & 3 & 3 & 3 & $1 / 6$ & $1 / 4$ & $1 / 2$ & $1 / 4$ & 1 & 2 & 3 & 3 & $1 / 8$ \\
\hline P10 & 7 & 5 & 5 & 6 & $1 / 6$ & $1 / 5$ & $1 / 3$ & $1 / 3$ & $1 / 2$ & 1 & $1 / 2$ & $1 / 3$ & $1 / 9$ \\
\hline P11 & 6 & 4 & 4 & 5 & $1 / 6$ & $1 / 4$ & $1 / 4$ & $1 / 4$ & $1 / 3$ & 2 & 1 & $1 / 4$ & $1 / 8$ \\
\hline P12 & 5 & 4 & 4 & 5 & $1 / 3$ & $1 / 4$ & $1 / 4$ & $1 / 4$ & $1 / 3$ & 3 & 4 & 1 & $1 / 8$ \\
\hline P13 & 2 & 3 & 4 & 4 & 5 & 7 & 8 & 8 & 8 & 9 & 8 & 8 & 1 \\
\hline
\end{tabular}

\subsection{Santralin Karlılık Durumu}

Elektrik santrallerinin kurulum ve işletme aşamasında oluşacak maliyetler bu madde kapsamında değerlendirilmiştir. Çalışma kapsamında belirlenen elektrik santrallerinin karlılık durumunu etkileyen unsurların değerlendirilebilmesi için altı alt kriter belirlenmiştir.

i. Santralin Yatırım Maliyeti: Elektrik santrallerinin kurulumu için gerekli olan yatırım maliyeti bu madde kapsamında değerlendirilmiştir.

ii. Santralin İşletme Giderleri: Elektrik santrallerinin tüm işletme giderleri bu madde kapsamında değerlendirilmiştir.

iii. Santralin Yakıt Giderleri: Elektrik santrallerinin yakıt giderlerinden doğan maliyet bu madde kapsamında değerlendirilmiştir.

iv. Elektrik İletim Hattı ve Trafo Yapım Maliyeti: Elektrik santralleri için EPDK tarafından inşaası zorunlu kılınan iletim hattı uzunluğu ve trafo yapım maliyetleri bu madde kapsamında değerlendirilmiştir. v. Santralin Başabaş Noktasının Analizi: Başabaş noktası toplam maliyet ve toplam gelirin eşit olduğu noktadır. Elektrik santrallerinin başabaş noktasının değerlendirmesi bu madde kapsamında irdelenmiştir.

vi. Dıșsal Maliyetler: Bir kararın bir başka karar üzerinde oluşturduğu fiyatlandırılamayan maliyetler değerlendirilmiştir. Bu maliyetler piyasa fiyatına yansımadığından dikkate alınmazlar. Elektrik üretiminin ve tüketiminin çevre ve insan sağlığ 1 üzerinde önemli dışsal etkileri bulunmaktadır. $\mathrm{Bu}$ etkiler özel maliyetler ile toplumsal maliyetler olarak birbirinden farklı iki etki oluşturur. $\mathrm{Bu}$ duruma örnek olarak kömür santralleri verilebilir. Kömür santrallerinde eski teknoloji kullanarak elektrik üretimi maliyet açısından uygun görülebilir ancak çevreye zararlı emisyonlar yaydığı için son derece kötüdür. Şöyle ki santraller zararlı emisyonlarından dolayı yöre halkının hastalanmasına ve çevre tahribatına neden olur; bu durumun düzeltilmesi için öngörülmeyen dışsal maliyetler bu madde kapsamında değerlendirilmiştir.

"Santralin Karlılık Durumu" ana kriterinin Karar Vericiler tarafindan değerlendirilmesi Çizelge 4'te sunulmuştur. 
Çizelge 4. Santralin karlılık durumu ana kriterinin ikili karşılaştırma matrisi

\begin{tabular}{|l|c|c|c|c|c|c|c|c|c|c|c|c|c|}
\hline & P1 & P2 & P3 & P4 & P5 & P6 & P7 & P8 & P9 & P10 & P11 & P12 & P13 \\
\hline P1 & 1 & 2 & 3 & 3 & 1 & $1 / 5$ & $1 / 7$ & $1 / 6$ & $1 / 4$ & $1 / 7$ & $1 / 7$ & $1 / 7$ & 3 \\
\hline P2 & $1 / 2$ & 1 & 1 & $1 / 2$ & $1 / 2$ & $1 / 6$ & $1 / 6$ & $1 / 4$ & $1 / 3$ & $1 / 7$ & $1 / 6$ & $1 / 5$ & 2 \\
\hline P3 & $1 / 3$ & 1 & 1 & $1 / 2$ & $1 / 2$ & $1 / 6$ & $1 / 6$ & $1 / 4$ & $1 / 3$ & $1 / 7$ & $1 / 6$ & $1 / 5$ & 3 \\
\hline P4 & $1 / 3$ & 2 & 2 & 1 & $1 / 2$ & $1 / 6$ & $1 / 6$ & $1 / 4$ & $1 / 3$ & $1 / 7$ & $1 / 6$ & $1 / 5$ & 3 \\
\hline P5 & 1 & 2 & 2 & 2 & 1 & $1 / 4$ & $1 / 8$ & $1 / 6$ & $1 / 6$ & $1 / 8$ & $1 / 8$ & $1 / 7$ & 3 \\
\hline P6 & 5 & 6 & 6 & 6 & 4 & 1 & $1 / 2$ & $1 / 2$ & $1 / 2$ & $1 / 3$ & $1 / 3$ & $1 / 3$ & 8 \\
\hline P7 & 7 & 6 & 6 & 6 & 8 & 2 & 1 & 3 & 3 & 2 & 3 & 3 & 8 \\
\hline P8 & 6 & 4 & 4 & 4 & 6 & 2 & $1 / 3$ & 1 & 2 & 2 & 2 & 2 & 8 \\
\hline P9 & 4 & 3 & 3 & 3 & 6 & 2 & $1 / 3$ & $1 / 2$ & 1 & $1 / 2$ & $1 / 2$ & $1 / 2$ & 7 \\
\hline P10 & 7 & 7 & 7 & 7 & 8 & 3 & $1 / 2$ & $1 / 2$ & 2 & 1 & $1 / 2$ & 2 & 8 \\
\hline P11 & 7 & 6 & 6 & 6 & 8 & 3 & $1 / 3$ & $1 / 2$ & 2 & 2 & 1 & 2 & 7 \\
\hline P12 & 7 & 5 & 5 & 5 & 7 & 3 & $1 / 3$ & $1 / 2$ & 2 & $1 / 2$ & $1 / 2$ & 1 & 6 \\
\hline P13 & $1 / 3$ & $1 / 2$ & $1 / 3$ & $1 / 3$ & $1 / 3$ & $1 / 8$ & $1 / 8$ & $1 / 8$ & $1 / 7$ & $1 / 8$ & $1 / 7$ & $1 / 6$ & 1 \\
\hline
\end{tabular}

\subsection{Santral Kurulum Durumu}

Çalışma kapsamında ülkemizdeki elektrik santrallerinin kurulumu ile ilgili kriterler değerlendirilmiştir, söz konusu ana kriterin değerlendirilmesi amacıyla beș alt kriter:

i. Santralin Kurulum Süresi: Elektrik santrallerinin kurulum süresi bu madde kapsamında değerlendirilmiştir.

ii. Santralin Yapım Kolaylığı: Kurulacak elektrik santrallerinin yapım yöntemlerinin değerlendirilmesi/kolaylığ 1 bu madde kapsamında değerlendirilmiştir.

iii. Mevcut Elektrik İletim Hattı Durumu: Elektrik santrallerinin kurulmasında en önemli kriterlerden birisi (özellikle yenilenebilir santraller için) elektrik iletim hattı yapısının (yüksek gerilim hattının) mevcudiyetidir. Enerji santralinin kurulacağı bölgede uygun gerilim hatları şebeke yapısının olup olmadığı bu madde kapsamında değerlendirilmiştir. iv. Elektrik Tüketim Noktalarına Yakınlığı: Kurulacak elektrik santrallerinin elektrik tüketim noktalarına yakınlığı bu madde kapsamında değerlendirilmiştir.

v. Coğrafi Yapı ile Uyumluluk: Kurulacak elektrik santrallerinin coğrafi uygunluğu/ uyumluluğu bu madde kapsamında değerlendirilmiştir. Bu duruma örnek olarak; ithal kömür santrallerinin deniz kıyısına kurulması verilebilir, uygun yapım yerleri seçilip seçilmediği bu madde kapsamında değerlendirilmiştir.

"Santral Kurulum Durumu" ana kriterinin Karar Vericiler tarafından değerlendirilmesi Çizelge 5'de sunulmuştur.

\subsection{Santral Birim Elektrik Üretim Maliyeti}

Ülkemizdeki elektrik santrallerinin elektrik üretim maliyetlerini etkileyen unsurlar değerlendirilmiştir, söz konusu ana kriterin değerlendirilmesi amaciyla dört alt kriterin Karar Vericiler tarafindan doldurulan alt maliyetleri ve puanı Çizelge 6'da sunulmuştur. 
Çizelge 5. Santral kurulum durumu ana kriterinin ikili karşılaştırma matrisi

\begin{tabular}{|l|c|c|c|c|c|c|c|c|c|c|c|c|c|}
\hline & $\mathrm{P} 1$ & $\mathrm{P} 2$ & $\mathrm{P} 3$ & $\mathrm{P} 4$ & $\mathrm{P} 5$ & $\mathrm{P} 6$ & $\mathrm{P} 7$ & $\mathrm{P} 8$ & $\mathrm{P} 9$ & $\mathrm{P} 10$ & $\mathrm{P} 11$ & $\mathrm{P} 12$ & $\mathrm{P} 13$ \\
\hline P1 & 1 & 1 & $1 / 2$ & $1 / 2$ & $1 / 3$ & 2 & $1 / 8$ & $1 / 5$ & $1 / 5$ & $1 / 6$ & $1 / 5$ & $1 / 5$ & 3 \\
\hline P2 & 1 & 1 & $1 / 2$ & $1 / 2$ & $1 / 3$ & 2 & $1 / 8$ & $1 / 5$ & $1 / 5$ & $1 / 6$ & $1 / 5$ & $1 / 5$ & 3 \\
\hline P3 & 2 & 2 & 1 & $1 / 2$ & $1 / 3$ & 2 & $1 / 8$ & $1 / 5$ & $1 / 5$ & $1 / 6$ & $1 / 5$ & $1 / 5$ & 4 \\
\hline P4 & 2 & 2 & 2 & 1 & $1 / 3$ & 2 & $1 / 8$ & $1 / 5$ & $1 / 5$ & $1 / 6$ & $1 / 5$ & $1 / 5$ & 4 \\
\hline P5 & 3 & 3 & 3 & 3 & 1 & 2 & $1 / 6$ & $1 / 4$ & $1 / 4$ & $1 / 4$ & $1 / 4$ & $1 / 4$ & 5 \\
\hline P6 & $1 / 2$ & $1 / 2$ & $1 / 2$ & $1 / 2$ & $1 / 2$ & 1 & $1 / 7$ & $1 / 6$ & $1 / 6$ & $1 / 6$ & $1 / 5$ & $1 / 5$ & 5 \\
\hline P7 & 8 & 8 & 8 & 8 & 6 & 7 & 1 & 3 & 3 & 2 & 3 & 3 & 9 \\
\hline P8 & 5 & 5 & 5 & 5 & 4 & 6 & $1 / 3$ & 1 & 2 & 2 & 2 & 2 & 9 \\
\hline P9 & 5 & 5 & 5 & 5 & 4 & 6 & $1 / 3$ & $1 / 2$ & 1 & $1 / 2$ & $1 / 2$ & $1 / 2$ & 8 \\
\hline P10 & 6 & 6 & 6 & 6 & 4 & 6 & $1 / 2$ & $1 / 2$ & 2 & 1 & $1 / 2$ & 3 & 9 \\
\hline P11 & 5 & 5 & 5 & 5 & 4 & 5 & $1 / 3$ & $1 / 2$ & 2 & 2 & 1 & 2 & 7 \\
\hline P12 & 5 & 5 & 5 & 5 & 4 & 5 & $1 / 3$ & $1 / 2$ & 2 & $1 / 3$ & $1 / 2$ & 1 & 7 \\
\hline P13 & $1 / 3$ & $1 / 3$ & $1 / 4$ & $1 / 4$ & $1 / 5$ & $1 / 5$ & $1 / 9$ & $1 / 9$ & $1 / 8$ & $1 / 9$ & $1 / 7$ & $1 / 7$ & 1 \\
\hline
\end{tabular}

Çizelge 6. Santral Birim elektrik üretim maliyeti ana kriterinin değerlendirilmesi

\begin{tabular}{|c|c|c|c|c|c|c|}
\hline Kaynak & $\begin{array}{c}\text { Santral İşletme } \\
\text { Maliyeti (\$Cent } \\
\text { /kWh) }\end{array}$ & $\begin{array}{l}\text { Santral Bakım } \\
\text { Maliyeti } \\
(\$ C e n t / k W h)\end{array}$ & $\begin{array}{c}\text { Santral } \\
\text { Rehabilitas. } \\
\text { Maliyeti } \\
\text { (\$Cent } / \mathrm{kWh})\end{array}$ & $\begin{array}{c}\text { Santral } \\
\text { Yakıt } \\
\text { Gideri } \\
\text { (\$Cent } \\
/ \mathrm{kWh})\end{array}$ & $\begin{array}{c}\text { Toplam: } \\
\text { Santral } \\
\text { Elekt. } \\
\text { Üretim } \\
\text { Maliyeti }\end{array}$ & Puan \\
\hline İthal Kömür & 0,97 & 2,12 & 5,15 & 2,61 & 10,85 & 0,0808 \\
\hline Taş Kömürü & 0,97 & 2,21 & 5,15 & 1,39 & 9,72 & 0,0902 \\
\hline Linyit & 0,97 & 3,08 & 5,15 & 1,96 & 11,16 & 0,0786 \\
\hline Asfalt. B.Şist & 0,97 & 2,21 & 5,15 & 1,51 & 9,84 & 0,0891 \\
\hline Doğalgaz & 0,68 & 5,08 & 4,15 & 3,6 & 13,51 & 0,0649 \\
\hline Hidrolik & 0,31 & 4,46 & 4 & 0 & 8,77 & 0,1000 \\
\hline Rüzgar & 0,61 & 2,66 & 3 & 0 & 6,27 & 0,1399 \\
\hline Jeotermal & 0,81 & 4,23 & 4,4 & 0 & 9,44 & 0,0929 \\
\hline Biyokütle & 0,75 & 6,12 & 4,1 & 0,5 & 11,47 & 0,0765 \\
\hline Güneş-PV & 0,61 & 8,71 & 5,11 & 0 & 14,43 & 0,0608 \\
\hline Güneş-CSP & 1,67 & 12,87 & 14,21 & 0 & 28,75 & 0,0305 \\
\hline Güneş-PTC & 1,67 & 13,34 & 14,65 & 0 & 29,66 & 0,0296 \\
\hline Nükleer & 1,02 & 3,22 & 8,02 & 1,02 & 13,28 & 0,0661 \\
\hline
\end{tabular}

6 ana kriterin kendi aralarında kıyaslanması sonucu Çizelge 7'de, kriterlere ait önem derecesi matrisi oluşturulan ikili karşılaştırmalar matrisi Çizelge 8'de sunulmuştur.

Çizelge 7. Ana kriterlerin ikili karşılaştırmalar matrisi

\begin{tabular}{|l|c|c|c|c|c|c|c|}
\cline { 2 - 8 } \multicolumn{1}{c|}{} & Kriterler & Kriter 1 & Kriter 2 & Kriter 3 & Kriter 4 & Kriter 5 & Kriter 6 \\
\hline Çevresel Etkenler & Kriter 1 & 1 & 9 & 8 & 9 & 8 & 5 \\
\hline Santral Teknolojisi Etkisi & Kriter 2 & $1 / 9$ & 1 & $1 / 5$ & $1 / 3$ & $1 / 4$ & $1 / 3$ \\
\hline Santralin Etkileri & Kriter 3 & $1 / 8$ & 5 & 1 & 2 & 2 & 3 \\
\hline Santral Karl1lik Durumu & Kriter 4 & $1 / 9$ & 3 & $1 / 2$ & 1 & 3 & 2 \\
\hline $\begin{array}{l}\text { Santral Kurulum Durumu } \\
\text { Maliyeti }\end{array}$ & Kriter 5 & $1 / 8$ & 4 & $1 / 2$ & $1 / 3$ & 1 & $1 / 2$ \\
\hline
\end{tabular}


Çizelge 8. Ana kriterlerin ikili karşılaştırmalar matrisinin önem derecesi

\begin{tabular}{|l|c|}
\hline Kriterler & Önem Derecesi \\
\hline Kriter 1: Çevresel Etkenler & 0,5391 \\
\hline Kriter 2: Santral Teknolojisi Etkisi & 0,0362 \\
\hline Kriter 3: Santralin Etkileri & 0,1568 \\
\hline Kriter 4: Santral Karlılık Durumu & 0,1117 \\
\hline Kriter 5: Santral Kurulum Durumu & 0,0719 \\
\hline Kriter 6: Santral Birim Elektrik Üretim Maliyeti & 0,0843 \\
\hline
\end{tabular}

Tutarlılık Göstergesi ve Tutarlılık Oranı hesaplanması: Çalışmada kullanılan 6 ana kriterler AHP skalasina göre KV'ler tarafindan puanlandıktan sonra ortalamaları alınmıştır, her bir satırın geometrik ortalaması alınarak "wi" sütun vektörü oluşturulur. Oluşturulan sütun vektörü normalize edilerek, göreli önemler vektörü " $\mathrm{W}_{\mathrm{i}}$ " hesaplanir.

Matristeki her bir satırın her bir elemanı göreli önemler vektörü $\left(\mathrm{W}_{\mathrm{i}}\right)$ sütunundaki elemanlarla çarpılıp toplanmasıyla $\mathrm{V}_{1}$ sütun vektörü elde edilir. $\mathrm{V}_{1}$ sütun vektörünün her elemanı, $\mathrm{Wi}$ vektöründe karşı gelen elemana bölünür ve $V_{2}$ vektörü hesaplanır. $\mathrm{V}_{2}$ sütun vektörünün aritmetik ortalaması alınarak da en büyük öz değer $\lambda_{\max }$ elde edilir.

Çalışmanın Tutarlılık Göstergesi (TG) ve Tutarlılık Oranı (TO) Eşitlik 1 ile hesaplanmıştır.
Tutarlılık Göstergesi $(\mathrm{TG})=\frac{\lambda \max -\mathrm{n}}{\mathrm{n}-1}$

$=($ Aw $/ \mathrm{w}-\mathrm{n}) /(\mathrm{n}-1)=(6,5594-6) /(6-1)=0,11189$

Rastlantısal Göstergesi-RG; Kwiesielewicz ve Uden [16]'e göre $n=6$ için 1,24 değeri alınmıştır.

$$
\begin{aligned}
\mathrm{TO}=\mathrm{TO} & =\frac{\text { Tutarlılık Göstergesi }(\mathrm{TG})}{\text { Rassalık Göstergesi }(\mathrm{RG})}=0,11888 / 1,24 \\
& =0,090233
\end{aligned}
$$

Tutarlılık Oranı (TO) Eşitlik 2'de hesaplanarak 0,090233 bulunmuştur, hesaplanan değer 0,1 'den küçük olduğu için çalışmanın kriterleri tutarlı ve kabul edilebilir düzeydedir.

Alt kriterleri AHP yöntemi [7] ile Karar Vericiler tarafından yapılmış ikili karşılaştırmaların sonuçları Çizelge 9'da ve önem derecesi matrisi ile çarpılarak hesaplanan göreli önem değerleri/öncelik değerleri; “enerji santrallerin puanı” Çizelge 10'da verilmiştir.

Çizelge 9. "Enerji santral seçimi” amacı ana kriterlerinin özet puan tablosu

\begin{tabular}{|l|c|c|c|c|c|c|}
\hline Kaynak & $\begin{array}{c}\text { Kriter1 } \\
\text { Cevresel } \\
\text { Etkenler }\end{array}$ & $\begin{array}{c}\text { Kriter2 } \\
\text { Santral } \\
\text { Teknolojisi } \\
\text { Etkisi }\end{array}$ & $\begin{array}{c}\text { Kriter3 } \\
\text { Santralin } \\
\text { Etkileri }\end{array}$ & $\begin{array}{c}\text { Kriter4 } \\
\text { Santral } \\
\text { Karl11k } \\
\text { Durumu }\end{array}$ & $\begin{array}{c}\text { Kriter5 } \\
\text { Santral } \\
\text { Kurulum } \\
\text { Durumu }\end{array}$ & $\begin{array}{c}\text { Kriter6 } \\
\text { Santral Birim } \\
\text { Elektrik Üretim } \\
\text { Maliyet Puan1 }\end{array}$ \\
\hline İthal Kömür & 0,0168 & 0,0148 & 0,0284 & 0,0301 & 0,0229 & 0,0808 \\
\hline Taş Kömürü & 0,0167 & 0,0216 & 0,0246 & 0,0202 & 0,0229 & 0,0902 \\
\hline Linyit & 0,0209 & 0,0266 & 0,0275 & 0,0210 & 0,0283 & 0,0786 \\
\hline Asfaltit Bit. Şist & 0,0229 & 0,0293 & 0,0341 & 0,0253 & 0,0311 & 0,0891 \\
\hline Doğalgaz & 0,0439 & 0,0385 & 0,1223 & 0,0258 & 0,0462 & 0,0649 \\
\hline Hidrolik & 0,0715 & 0,1121 & 0,1148 & 0,0832 & 0,0218 & 0,1000 \\
\hline Rüzgar & 0,1642 & 0,2078 & 0,0767 & 0,1996 & 0,2252 & 0,1399 \\
\hline Jeotermal & 0,1645 & 0,0847 & 0,0785 & 0,1319 & 0,1414 & 0,0929 \\
\hline Biyokütle & 0,1274 & 0,0701 & 0,0537 & 0,0764 & 0,0946 & 0,0765 \\
\hline Güneş-PV & 0,1204 & 0,1518 & 0,0577 & 0,1328 & 0,1313 & 0,0608 \\
\hline Güneş-CSP & 0,1169 & 0,1341 & 0,0525 & 0,1363 & 0,1238 & 0,0305 \\
\hline Güneş-PTC & 0,1049 & 0,0963 & 0,0627 & 0,1051 & 0,0993 & 0,0296 \\
\hline Nükleer & 0,0091 & 0,0123 & 0,2665 & 0,0124 & 0,0112 & 0,0661 \\
\hline
\end{tabular}


Çizelge 10. Enerji santrallerin puanı

\begin{tabular}{|l|c|}
\hline Kullandığı Kaynak & Enerji Santralinin Puan \\
\hline Rüzgar-Yeni & 0,1585 \\
\hline Jeotermal-Yeni & 0,1377 \\
\hline Güneş-PV: Fotovoltaik- Yeni & 0,1090 \\
\hline Güneş-CSP: Odaklanmış Güneş Enerjisi- Yeni & 0,1030 \\
\hline Biyokütle- Yeni & 0,1022 \\
\hline Güneş-PTC: Parabolik Oluk Kolektör- Yeni & 0,0914 \\
\hline Hidrolik-Yeni & 0,0797 \\
\hline Doğalgaz-Yeni & 0,0555 \\
\hline Nükleer & 0,0531 \\
\hline Asfaltit ve Bitümlü Şist-Yeni & 0,0313 \\
\hline Taşkömürü-Yeni & 0,0275 \\
\hline İthal kömür-Yeni & 0,0259 \\
\hline Linyit-Yeni & 0,0252 \\
\hline
\end{tabular}

\section{SONUÇLAR}

Literatürdeki çalışmalarda sıklıkla kullanılan/dikkate alınan enerji santrali seçimi için çalışmada ÇKKV yöntemi olan AHP metodolojisine göre ülkemizde kullanılan/ kullanılacak olan 13 enerji santrali 6 ana kriterli ve ilgili 31 alt kriter ile çok ölçütlü bir karar problemi olarak detaylı bir şekilde KV'lerle görüşülerek puanlandırılmıştır. Ülkemizde elektrik üretimi yapan enerji santralleri; ithal kömür, taşkömürü, linyit, asfaltit ve bitümlü şist, doğalgaz, hidroelektrik, rüzgar, jeotermal, biyokütle, güneş (PV)'dir. Güneş (CSP, PTC) enerji santralleri ise daha verimli olduğu için yakın bir gelecekte ETKB tarafından kullanılmaya başlanacaktır. Ülkemizin elektrik enerjisi üretiminde kullanılan enerji kaynakları; çevresel etkenler, santral teknolojisinin etkisi, santralin etkileri, santralin karlılık durumu, santralin kurulum durumu, santral birim elektrik üretim maliyeti ana kriterleri altında ele alınmıştır. Ülkemizin ithal ettiği enerji kaynakları; petrol, doğalgaz, ithal kömürdür ve enerji tüketimimizinde önemli bir kısmını oluşturmaktadır. Ülkemiz yenilenebilir kaynak potansiyeli yüksek bir ülke olduğundan yerli ve yenilenebilir kaynak kullanan yatırımların önü açılmalı bunu bir enerji politikası altında planlamalıdır. Bu kapsamda Enerji ve Tabii Kaynaklar Bakanlığı (ETKB)'nın 2023 yılı hedeflerini içeren "Elektrik Piyasası ve Arz Güvenliği Strateji Belgesi" nde [17] yer alan stratejik tüm (yerli ve yenilenebilir kaynak kullanım) hedeflerini gerçekleştirmek için azami çaba harcanmalıdır.

Çalışmada AHP yöntemine göre hesaplanan Çizelge 10'da yer alan "Enerji Santrallerin Puanı" na göre fosil yakıtll, yenilenebilir ve nükleer enerji santralleri arasında bir dağılım yapılması gerektiğinde; ülkemiz için ETKB'nın 2023 yılı enerji hedefleri ile uyumlu olan yenilenebilir ağırlıklı bir senaryo ortaya çıkmıştır. Çalışmada elde edilen sonuçlar incelendiğinde ülkemize en uygun olarak seçilen enerji santrali; rüzgar enerji santralleridir. ETKB'nın 2023 yılına kadar rüzgar potansiyelinin 20.000 MW (73.333,3 GWh) kullanmayı hedeflemesi pozitif bir sosyal alg1 oluşturmuş, ayrıca kaynak potansiyelinin 144.000 GWh olması ise bu enerji kaynağını ilk sırada kullanılmasında/seçiminde önemli bir etken olmuştur. Bunu sırasıyla, jeotermal, güneş, biyokütle, hidrolik, doğal gaz, nükleer, asfaltit ve bitümlü şist, taş kömürü, ithal kömür, linyit izlemektedir. Ayrıca model için yapılan analizler için tutarlılık oranı/endeksi sonucunun 0,1 değerinden küçük olması analizin tutarlı olduğunu göstermektedir. Çizelgedeki puanlardan görüleceği üzere; yenilenebilir kaynaklı santrallerin puanları yüksek iken çevreyi kirleten fosil yakıtlı santrallerin puanları düşüktür. Yenilenebilir kaynaklı santrallerin proje alanları, sera gazı salınımları, çevreye zararları, kapladığı alan, bakım/onarım giderleri, çevreye etkileri diğer santrallere göre daha azdır. Bu sebepten dolayı KV'ler tarafindan daha yüksek puan verilerek tercih edilmiştir. 
Yenilenebilir santrallerin kullanım sıralaması ise rüzgar, jeotermal, güneş, biyokütle ve hidrolik enerji santralleri olup bunun sebebi ise santrallerin işletme ve bakım maliyetinin düşüklüğü ve bakım kolaylığıdır. Ülkemizde kurulacak nükleer santrallerde son nükleer teknolojiler kullanılacak olmasına rağmen Fukuşima nükleer santralindeki kazadan dolayı dünya genelinde nükleer santrallere karş1 bir tepki, güvensizlik oluştuğundan \%5,31 ile listenin son sıralarında yer almaktadır.

Güneş santrallerinin toplam puanı (PV, CSP, PTC toplamı) diğer santrallere göre daha yüksektir. Bunun temel nedenleri arasında dünya genelinde güneş santralleri projelerinin büyük bir atak içerisinde olmasıdır (Sahra Projesi gibi), son yıllarda güneş santralleri teknolojilerinde büyük gelişim sağlanmasıdır. Bu duruma rağmen ETKB 2023 y1lı enerji hedeflerinde güneş enerjisi kurulu gücünü 3.000 MW (4.880 GWh) [17] gibi çok az bir değere çıkarmayı hedeflemiştir. Bu hedef toplam güneş kaynak potansiyelinin 78'de biridir (kaynak potansiyeli $380.000 \mathrm{GWh} / \mathrm{y}$ ll) ve EPDK tarafından hala lisanslı üretim başvuru sonuçlarının açıklanmaması günümüzdeki pozitif algının negatife dönme riskini artırmaktadır. Yenilenebilir kaynaklı santrallerden; güneş santrallerinin her biri (PV, CSP, PTC) ayrı ayrı puanları ile biyokütle santrallerinin puanları $\% 10$ civarındadır.

Hidrolik santrallerinin puanı \%7,97'dir. Bunun sebebini ise: ETKB'nın 2023 yılına kadar hidro kaynaklarımızın ekonomik potansiyeli olan 39 GW'tan (140.000 GWh) faydalanmayı hedeflemesi [17] pozitif bir alg1 oluşturmasına rağmen hidroelektrik santrallerinin yüksek kurulum maliyetinin olması ve büyük su rezervuarlarının ekilen verimli toprakları suyun altında bırakması hidroelektrik santrallerden karar vericilerin uzaklaşmasına neden olmuştur. Jeotermal kaynak potansiyelinin çok az olması (15.200 GWh/yıl) söz konusu santral tipinin ikinci sirada olmasina neden olmuştur. Bu sebepten dolayı acilen ülkemizde yeni sondajlarla yeni jeotermal kaynaklarımız araştırılması ve yeni kaynaklarımızın bulunması gereklidir. Biyokütle kaynak potansiyelinin az olması (93.000 GWh/yıl) söz konusu santral tipinin beşinci sırada olmasına neden olmuştur. Fosil kaynaklar içinde en yüksek puanı doğal gaz almış olup bunun sebebi ise diğer fosil yakıtlara göre daha temiz bir yakıt olmasıdır. Kömür yakıtları içinde en az puanı linyit almıştır. Sebebi ise; kaynağın çevreyi kirletmesidir. Taşkömürünün puanı linyite göre biraz daha fazladır. $\mathrm{Bu}$ durum; ülkemizin taşkömürü ve linyit gerçeği ile paralellik göstermektedir. Ülkemizdeki linyit kömürü taşkömürüne göre kalorifik değeri daha düşüktür. Fakat ülkemizin taşkömürü yatakları açısından zengin değildir, linyit açısından ise zengin bir konumdadır. Ülkemiz yerli ve yenilenebilir kaynak kullanımını artıracak yeni bir enerji senaryosunu ivedilikle gerçekleştirmek için çalışmalarını başlatmalı enerji santrallerinin planlamasını yapmalidir.

\section{KAYNAKLAR}

1. İncekara, Ç.Ö., 2017. Türkiye'nin Sürdürülebilir Stratejik Enerji Politikalarının Oluşturulması için Optimizasyon Modellerinin Geliştirilmesi ve Uygulama Adımları. Doktora Tezi. Çukurova Üniversitesi, Adana.

2. İncekara, Ç.Ö., Oğulata, S.N., 2012. EU and Turkey's Energy Strategies, International Conference on Business. Management, Economics and Finance, 35-43, İzmir.

3. İncekara, Ç.Ö., Oğulata, S.N., 2010. Dünya'nın ve Türkiye'nin Enerji Senaryoları. YAEM 2010, Sabancı Üniversitesi. İstanbul, 128-139.

4. Enerji Tabii Kaynaklar Bakanlığı (ETKB), 2016. Enerji Raporu. ETKB, 23-84.

5. Zionts, S., 1979. MCDM-If not a Roman Numeral Then What? Interfaces, C.9(4)

6. Saaty, T.L., 1991. Some Mathematical Concepts of the Analytic Hierarchy Process. Behaviormetrika, No. 29: 19-25.

7. Saaty, T.L., 1980. The Analytic Hierarchy Process. McGraw-Hill, 55-88, New York, ABD.

8. Zahed, F., 1987. A Utility Approach to the Analytic Hierarchy Process. Mathematical Modelling, 9(3-5), 41-66.

9. Borges, A.R., Antunes, C.H., 2003. A Fuzzy Multiple Objective Decision Support Model for Energy-Economy Planning. European Journal of Operational Research, 145, 304-316.

10. Burnaz, S., Topçu, Y.I., 2006. A Multiple Criteria Decision-making Approach for the 
Evaluation of Retail Location. Journal of Multi Criteria Decision Analysis, 14, 67-76.

11. Chen, C.F., 2006. Applying the Analytical Hierarchy Process (AHP) Approach to Convention Site selection. Journal of Travel Research, 45(3), 167-174.

12. Hatzimouratidis, A.I., Pilavachi, P.A., 2007. Objective and Subjective Evaluation of Power Plants and Their Non-radioactive Emissions Using the Analytic Hierarchy Process. Energy Policy, 35(8), 4027-4038.

13. Yang J., Lee, H., 1997. An AHP Decision Model for Facility Location Selection. Facilities, 15. (9/10), 241-254.

14. Banai-Kashani, R., 1989. A New Method for Site Suitability Analysis: The Analytic Hierarchy Process. Environmental Management, 13(6), 685-693.

15. Vargas, L.G., 1990. An Overview of the Analytic Hiyerarchy Process and its applications. European Journal of Operational Research, 48, 49-62.

16. Kwiesielewiczk, M., Uden, E.V., 2004. Inconsistent and Contradictory Judgements in Pairwaise Comparison Method in the AHP. Computers \& Operations Research, 31-33.

17. Enerji ve Tabii Kaynaklar Bakanlığı, 2010. Enerji ve Tabii Kaynaklar Bakanlığı 2010- 2014 Stratejik Planı. 25-30, ETKB. 